\title{
A Research on Causes of Underemployment of Engineering Graduates through Quality Control (QC) Tool - Affinity Diagram (KJ Method)
}

\section{S.Bhaskar}

\begin{abstract}
More than unemployment, the issue faced by the youth in India is debated to be underemployment. The objective of the study is to identify the causes for underemployment as perceived by the Under Graduate (UG) Engineering and Technology (E\&T) students. The methodology involves collecting data on the causes of underemployment from $U G E \& T$ students at the verge of graduation and grouping the thus collected data. The Quality Control (QC) Tool - Affinity Diagram has been used in this study to collect data as it is an approach that enables data collection by protecting the identity of the data giver. The first phase of using the tool involves collecting data as experienced and perceived by the data giver. The second phase, involves grouping of the data collected in phase one of the methodology and assigning a relevant group title. It has been concluded that such data grouped under relevant heads when provided to aspirants of $U G E \& T$ programs will enable the aspirants to: 1. Better understand the causes for underemployment and 2. Guide them to take actions at the optimal time during their student hood to attain the needful attributes to be employable immediately after graduation.
\end{abstract}

Keywords - Unemployment, Underemployment, QC Tools, Affinity Diagram

\section{INTRODUCTION}

Aspirants entering UG E\&T programs in India will be able to direct their efforts to get employment when they graduate if authentic information on facts leading to underemployment is provided to them at an optimal time. Underemployment in this paper implies getting into low paying jobs and careers not suiting their qualification due to not being knowledgeable and skillful because of lack of preparation during graduation. A critical problem today is lack of availability of essential facts that guide in taking worthwhile decisions by the students. Casually passed on comments and perceptions seldom stand to guide students in taking life changing decisions. When such information is tried to be collected from students at the verge of graduation through traditional feedback systems, due to fear of identity being revealed they rarely provide genuine information. Fear to provide feedback is mainly due to the thought that they will be cornered by the academicians and power centers of the academic ecosystem they belongs to

Literature review reveals the following. Plans that are sustainable have been developed by combining concepts of Affinity Diagram with other techniques for creating solutions under narrow quantitative information [1]. In joint group discussion situation, the regular brainstorming technique of using sticky notes has been a vital part in many occasions. In spite of the available technologies to support group brainstorming, even today many feel it is practical and convenient to bank on the traditional paper-based dialogue methods to collect, organize and exchange ideas with others [2]. For speedily organizing information, Affinity diagram is an apt technique. For organizing information that is unsystematic, unclear, not in order and the like, Affinity Diagrams are used [3]. The KJ method is used to improve the results of the conventional Delphi method, and can also be used with Severity Index computation to rank information [4]. The results of the affinity cluster by KJ Method are a way directed towards development [5]. Workflow has been introduced with many methods that includes affinity diagram and all have been integrated into technologies. The analytical results of the various methods have been compared and Affinity diagrams have been practical and useful [6]. Investigation of customer desires is a significant step in successful product development and affinity diagram approach has been used to identify customer needs and grouping them for better understanding of the needs [7].

In this paper, authentic data on causes of underemployment of UG E\&T graduates has been collected from a group of students at the verge of graduation. The technique used will not reveal the identity of the information given. The collected information in then grouped under certain heads to enable aspirants entering UG E\&T programs to use it for taking informed decisions at an optimal time to prepare for their careers.

This research paper consists of three parts. The introductory part that includes literature review is the first part. The second part covers the study conducted and the concluding remarks have been made in the third part.

\section{DISCUSSION \& RESULTS}

The objective of this work is to collect and group authentic information on facts leading to underemployment of UG E\&T graduates in the perception of students at the verge of completing their UG E\&T program. 


\section{A RESEARCH ON CAUSES OF UNDEREMPLOYMENT OF ENGINEERING GRADUATES THROUGH QUALITY CONTROL (QC) TOOL - AFFINITY DIAGRAM (KJ METHOD)}

\section{A. Phase 1: Authentic Information Collection to Prepare an Affinity Diagram}

The popular method used for idea generation is brainstorming but it has its limitation of revealing the identity of the information giver. Due to fear of being noticed, information givers usually do not come forward to express. Hence, in the process of developing an Affinity Diagram, brainstorming is used with a way of using stick sheet (note pads that can be stuck). Information is asked to be written on a stick sheet and the sheet is stuck randomly on a white board. Any numbers of stick sheets are provided to participants of a group to provide information. The person who gives the information doesn't reveal identity on the stick sheet and hence fear of being cornered due to giving information vanished in this process. Affinity diagrams are created by following Step-1 to Step-7 as detailed in appropriate places of this paper.

The study was conducted in a class consisting of 35 students,. The objective was to first gather authentic information on causes of underemployment of engineering graduates. . In the first phase, information to create an Affinity diagrams was gathered as follows: Step-1: Organizing a group of student (35 students in this study) at the verge of graduation who have information on the topic of concern. Step-2: Providing stick sheets to each participant in the group and enabling them to transfer information on to the sheet without bias. Step-3: Scattering the stick sheets on a white board.

The information collected is shown in table 1: scrambled information

\section{Table 1: Scrambled Information (on Causes of Underemployment)}

\begin{tabular}{|c|c|}
\hline $\begin{array}{l}\text { Point } \\
\text { No }\end{array}$ & Causes of Underemployment \\
\hline 1 & $\begin{array}{l}\text { Wrong perception of reality created by } \\
\text { society }\end{array}$ \\
\hline 2 & $\begin{array}{l}\text { Outdated syllabus and facilities in } \\
\text { educational institutions }\end{array}$ \\
\hline 3 & $\begin{array}{l}\text { Students comparing themselves with non } \\
\text { performing peers }\end{array}$ \\
\hline 4 & Electronic gadgets with diverting content \\
\hline 5 & $\begin{array}{l}\text { Students taking advantage of climatic } \\
\text { conditions }\end{array}$ \\
\hline 6 & Lethargic education system \\
\hline 7 & Minimum use of opportunity by students \\
\hline 8 & $\begin{array}{l}\text { Business centric approach of academic } \\
\text { ecosystem }\end{array}$ \\
\hline 9 & $\begin{array}{l}\text { No follow up from parents as both parents } \\
\text { are working }\end{array}$ \\
\hline 10 & $\begin{array}{l}\text { Students lack of concentration on physical } \\
\text { fitness }\end{array}$ \\
\hline 11 & Students banking on the assets of parents \\
\hline 12 & $\begin{array}{l}\text { Availability of diverting content in social } \\
\text { media }\end{array}$ \\
\hline 13 & Automation for all basic activities \\
\hline 14 & Misuse of machines and vehicles by students \\
\hline 15 & $\begin{array}{l}\text { Inability to multi task and work based on } \\
\text { priority }\end{array}$ \\
\hline 16 & Drop in motivation due to categorization of \\
\hline
\end{tabular}

\begin{tabular}{|c|c|}
\hline & $\begin{array}{l}\text { the system that is based on exam } \\
\text { performance }\end{array}$ \\
\hline 17 & Free availability of unwanted things \\
\hline 18 & Addiction to bad habits \\
\hline 19 & Attitude of society that seldom encourages \\
\hline 20 & $\begin{array}{l}\text { Priority of the educational system on } \\
\text { physical presence than on performance }\end{array}$ \\
\hline 21 & $\begin{array}{l}\text { Misguidance of school teachers on transition } \\
\text { between school and college }\end{array}$ \\
\hline 22 & $\begin{array}{l}\text { Availability of attractive tourist spots in the } \\
\text { near vicinity }\end{array}$ \\
\hline 23 & $\begin{array}{l}\text { Institution owners forcing on things not } \\
\text { needed for career preparation }\end{array}$ \\
\hline 24 & Addiction to mobile games \\
\hline 25 & Improper time management \\
\hline 26 & Preference based on community \\
\hline 27 & Diverting culture / nature of society \\
\hline 28 & Decisions being forced by elders \\
\hline 29 & Failing concluded as failure \\
\hline 30 & Availability of options for everything \\
\hline
\end{tabular}

B. Phase 2: Grouping of the Authentic Information to form an Affinity Diagram

The information on the issue under the scope of study is usually fuzzy and difficult to understand. Hence, categorizing the information will enable to understand the information better. The "Affinity Diagram" was further created by categorizing the information collected in phase one of the studies as follows. Step-4: Dividing the group into smaller groups of 3 or 4 persons in a group. Step-5: Have one group arrange the information (Stick Sheets) without intervention from the other groups. Step-6: Have the second group refine the work of the first group; the third group refines the work of the second group and the like, until all groups have worked on grouping the information. Step-7: Now each group of information is given a title by adapting the process of brainstorming.

The students who provided the information categorized the information and provide an appropriate descriptive heading for each category. Six categories evolved. The results obtained due to the above process has been shown in figure 1: Affinity Diagram (ordered information)

Fig.1. Affinity Diagram (Ordered Information on Causes of Underemployment)

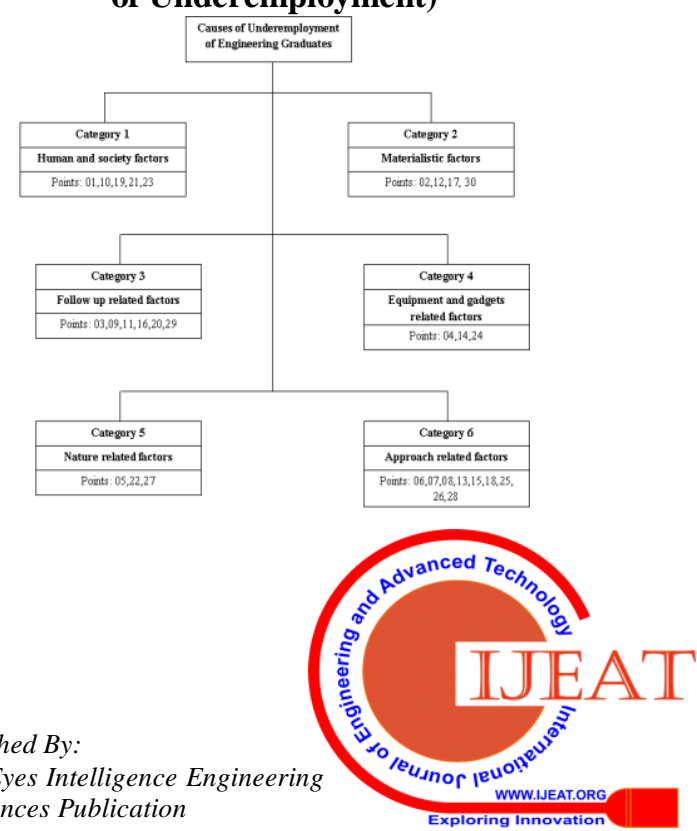




\section{CONCLUSION}

The study has identified and listed the causes of underemployment of Engineering Graduates under six categories and the same as been provided as an Affinity Diagram that has put in order information that was initially scrambled. The authentic information available under the six categories will be an eye opener to freshmen undergoing UG E\&T programs to look into and make use of with appropriate decisions to enhance their career prospects and become knowledgeable, skillful and develop the right attitude to become fittingly employable.

\section{REFERENCES}

1. Anjali Awasthi et al., A hybrid approach integrating Affinity Diagram, AHP and fuzzy TOPSIS for sustainable city logistics planning, Applied Mathematical Modeling 36 (2012) 573-584, doi:10.1016/j.apm.2011.07.033

2. William Widjaja et al., Discusys: Multiple User Real-time Digital Sticky-Note Affinity-Diagram Brainstorming System, Procedia Computer Science 22 ( 2013 ) 113 - 122

3. www.asq.org [Building an affinity for K-J Method March 2007, Pg. 88

4. Ying-Mei Cheng, An exploration into cost-influencing factors on construction projects, International Journal of Project Management 32 (2014) 850-860

5. Anitawati Mohd Lokma et al., Kansei Affinity Cluster for Affective Product Design, 2010 International Conference on User Science Engineering (i-USEr), pg. 38 - 43

6. Bin Luo et al., Visualized Clustering of Ideas for Group Argumentation, 2010 IEEE/WIC/ACM International Conference on Web Intelligence and Intelligent Agent Technology, DOI 10.1109/WI-IAT.2010.280

7. Shun Takai et al., A Use of Subjective Clustering to Support Affinity Diagram Results in Customer Needs Analysis, Concurrent Engineering OnlineFirst, published on May 12, 2010 as doi:10.1177/1063293X10372792

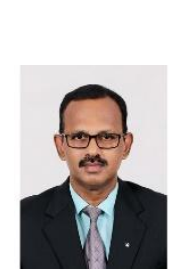

\section{AUTHOR BIOGRAPHY}

Associate Professor in Mechanical Engineering Department at Kumaraguru College of Technology (KCT), Coimbatore, India. Has experience of 27+ years in teaching at KCT and 01 year in industry and is an All India Management Association (AIMA) certified trainer. Has authored books on topics related to engineering, management and student development. Has his knowledge made available to the world through his YouTube channel "Trainer Bhaskar". 